\title{
VIOLÊNCIA URBANA E VULNERABILIDADES: OS DISCURSOS DOS JOVENS E AS NOTÍCIAS DE \\ JORNAIS
}

Carolina Salomão Correa

Esta pesquisa expressa uma preocupação em relação à maneira como a juventude contemporânea vem lidando com o estado de violência urbano e vulnerabilidades ao qual estão submetidos. No Brasil os dados mostram que os jovens entre 15 e 24 anos constituem a parcela da população mais exposta a violências externas, tais como homicídios e acidentes de trânsito. A pesquisa partiu da coleta e reunião de notícias de jornais referentes a situações de óbitos e vulnerabilidades envolvendo os jovens. As reportagens, além de demonstrarem a realidade no campo social, serviram de ponto de partida para um amplo debate com jovens de diferentes segmentos sociais acerca da condição da juventude na contemporaneidade. O objetivo foi incentivar a reflexão sobre o modo como a violência urbana e a vulnerabilidade afetam a experiência subjetiva da juventude no contemporâneo, oferecendo subsídios para os profissionais da área criarem alternativas intervencionistas de caráter preventivo.

BANCA:

Solange Jobim e Souza (Orientação)

Eliane Ribeiro Andrade

Regina Célia Reys Novaes

Data de defesa: 29/03/2010 